\title{
Evaluation of caregivers' knowledge, beliefs and practices regarding oral lesions in HIV-patients: A pilot study
}

\begin{tabular}{|c|c|}
\hline \multicolumn{2}{|c|}{$\begin{array}{l}\text { Authors: } \\
\text { Yolanda Kolisa }{ }^{1,2} \\
\text { Olalekan Ayo-Yusuf }^{1}\end{array}$} \\
\hline \multicolumn{2}{|c|}{$\begin{array}{l}\text { Affiliations: } \\
{ }^{1} \text { Department of Community } \\
\text { Dentistry, University of } \\
\text { Pretoria, South Africa }\end{array}$} \\
\hline \multicolumn{2}{|c|}{$\begin{array}{l}{ }^{2} \text { Department of Community } \\
\text { Dentistry, University of } \\
\text { Witwatersrand, South Africa }\end{array}$} \\
\hline \multicolumn{2}{|c|}{$\begin{array}{l}\text { Correspondence to: } \\
\text { Yolanda Kolisa }\end{array}$} \\
\hline \multicolumn{2}{|c|}{$\begin{array}{l}\text { Email: } \\
\text { yolanda.kolisa@up.ac.za }\end{array}$} \\
\hline \multicolumn{2}{|c|}{$\begin{array}{l}\text { Postal address: } \\
\text { PO Box 1266, Pretoria 0001, } \\
\text { South Africa }\end{array}$} \\
\hline \multicolumn{2}{|c|}{$\begin{array}{l}\text { Dates: } \\
\text { Received: } 02 \text { Oct. } 2012 \\
\text { Accepted: } 28 \text { Mar. } 2013 \\
\text { Published: } 10 \text { Sept. } 2013\end{array}$} \\
\hline \multicolumn{2}{|c|}{$\begin{array}{l}\text { How to cite this article: } \\
\text { Kolisa, Y. \& Ayo-Yusuf, } \\
\text { O., 2013, 'Evaluation of } \\
\text { caregivers' knowledge, } \\
\text { beliefs and practices } \\
\text { regarding oral lesions in } \\
\text { HIV-patients: A pilot study', } \\
\text { Health SA Gesondheid 18(1), } \\
\text { Art. \#704, } 8 \text { pages. http:// } \\
\text { dx.doi.org/10.4102/hsag. } \\
\text { v18i1.704 }\end{array}$} \\
\hline \multicolumn{2}{|c|}{$\begin{array}{l}\text { Copyright: } \\
\text { (C) 2013. The Authors. } \\
\text { Licensee: AOSIS } \\
\text { OpenJournals. This work } \\
\text { is licensed under the } \\
\text { Creative Commons } \\
\text { Attribution License. }\end{array}$} \\
\hline \multicolumn{2}{|l|}{ Read online: } \\
\hline 口ida & $\begin{array}{l}\text { Scan this QR } \\
\text { code with your } \\
\text { smart phone or } \\
\text { mobile device } \\
\text { to read online. }\end{array}$ \\
\hline
\end{tabular}

Seventy to ninety percent of HIV-infected individuals have oral lesions that affect their qualityof-life. Caregivers play an important role in complementing the healthcare team. It is essential that the caregivers have optimal knowledge, beliefs and practices toward the management of care regarding oral-lesions in HIV-infected patients in caregiving institutions in Johannesburg, South Africa. To measure the knowledge, beliefs and practices relating to oral lesions in HIV infection amongst caregivers in caregiving institutions in Johannesburg. This cross-sectional pilot study conducted during 2005 and 2006 involved caregivers in palliative care institutions in Region 8, Johannesburg Metropolitan area $(n=52)$. Using a questionnaire, information obtained included demographics, knowledge, beliefs and practices with regard to oral care for HIV-positive patients. Principal component analysis was used to extract questionnaire items of the knowledge domain. The knowledge domain displayed excellent internal consistency (Cronbach $\alpha$-score of $>0.91$ ). Of the caregivers, $65.4 \%$ had received training in oral care. Compared to caregivers not trained in oral care (NTOC), those caregivers trained in oral care (TOC) were more likely to be older (31 yrs vs. $44 \mathrm{yrs} ; p=0.001)$, female ( $72 \%$ vs. $94 \% ; p=0.03$ ) and were less likely to be employed on a full-time basis $(94 \%$ vs. $68 \% ; p=0.03)$. Compared with NTOCs, TOCs had more knowledge regarding HIV-specific lesions and 'routine' oral-care for the patients $(p<0.005)$. Similarly, TOC caregivers had more positive beliefs about oral care for those living with HIV $(p<0.05)$. Offering training in oral healthcare to caregivers improves their knowledge of oral lesions and their beliefs about oral care.

Sewentig tot negentig persent van MIV-geïnfekteerde individue mondelinge letsels wat hul kwaliteit van lewe. Versorgers speel 'n belangrike rol in die aanvulling van die gesondheidsorg span. Dit is noodsaaklik dat die versorgers het ' $n$ beter kennis, oortuigings en praktyke na die bestuur van sorg met betrekking tot mondelinge letsels in MIV-geïnfekteerde pasiënte in die versorgingstaak van instellings in Johannesburg, Suid-Afrika. Om die kennis, oortuigings en praktyke met betrekking tot mondelinge letsels in MIV-infeksie onder versorgers in die versorgingstaak van instellings in Johannesburg te meet. Hierdie deursnee-loodsstudie uitgevoer gedurende 2005 en 2006 betrokke versorgers in palliatiewe sorg instellings in Streek 8 , Johannesburg Metropolitaanse gebied $(n=52)$. Met behulp van ' $n$ vraelys, inligting ingesluit demografie, kennis, oortuigings en praktyke met betrekking tot mondelinge sorg vir MIVpositiewe pasiënte. Principal component analise is gebruik om vraelys items te onttrek van die kennis domein. Die kennis domein vertoon uitstekende interne konsekwentheid (Cronbach -telling van $>0,91$ ). Van die versorgers, het $65.4 \%$ ontvang opleiding in mondelinge sorg. Vergeleke met versorgers wat nie opgelei in mondelinge sorg (NTOC), die versorgers opgelei in mondelinge sorg (TOC), was meer geneig om ouer (31 jaar teen 44 jaar; $p=0.001)$, vroue (72\% teen $94 \% ; p=0.03)$ en is minder geneig om te word op ' $n$ voltydse basis $(94 \%$ teen $68 \%, p=0.03)$ in diens geneem. Vergeleke met NTOCs, TOCs versorgers het meer kennis aangaande MIVspesifieke letsels en roetine 'mondelinge sorg vir die pasiënte $(p<0,005)$. TOC versorgers het meer positiewe oortuigings oor mondelinge sorg vir diegene wat met MIV $(p<0.05)$. Aanbod opleiding in mondelinge gesondheidsorg te versorgers verbeter hul kennis van mondelinge letsels en hulle oortuigings oor mondelinge sorg.

\section{Introduction}

\section{Significance of work}

A holistic team approach has been proposed to be a lasting solution for the management of many medical conditions, especially the management of HIV. Studies done throughout the world indicate that oral lesions associated with HIV occur in over half of HIV patients. These oral lesions have physical, social and psychological consequences for the patient and seriously impair the quality of life in affected individuals. There is therefore a need to provide services to 
alleviate oral health problems and improve patient comfort. In order for the effective management of HIV including oral manifestations of the disease to be realised fully, knowledge and beliefs regarding the oral manifestations of HIV infection by all professional and lay people involved in the care and support of patient is essential. Caregivers in nongovernmental institutions (NGOs) play an important role in complementing the healthcare team and they are pivotal in offering care and support in the management of HIV including the management of oral lesions. For the caregivers to be able to manage the disease in its entirety, they need optimal knowledge of all aspects of HIV, including the oral manifestations associated with the illness. Evaluation of their current knowledge and belief status is thus important.

\section{Problem statement}

With the increasing burden of Human Immunodeficiency Virus (HIV) in South Africa (SA) (Human Sciences Research Council 2008), the care and support of HIV patients has already brought about a great need for community-based, home-based and hospice institutions and good practice on the part of the people who staff these institutions.

In the City of Johannesburg, the care of and support for the people infected and affected by HIV and AIDS in 2006 was limited to 30 non-governmental organisations (NGOs) and community-based organisations (CBOs). Community caregivers employed in these NGOs and CBOs are trained in home care and counselling according to national guidelines (Department of Health 2001). Having the appropriate knowledge of oral health and oral diseases related to HIV infection is essential so that caregivers can provide a general as well as an oral healthcare package of services to patients.

\section{Aim of the study}

This study was conducted to measure the levels of knowledge of, beliefs about and practices (KBP) relating to oral lesions in $\mathrm{HIV}$ infection amongst caregivers who are employed by the NGOs and CBOs in Johannesburg, South Africa.

\section{Literature review}

Studies done throughout the world indicate that oral lesions associated with HIV occur in over $50 \%$ and up to $80 \%$ of HIV patients (Coogan, Greenspan \& Challacombe 2005:705; Lim et al. 2002:605-606). These oral lesions have serious consequences for patients and impair their oral-healthrelated quality of life (Malele 2007:41; Yengopal \& Naidoo 2008:71). There is, therefore, a need to provide services to alleviate oral problems and improve patient comfort.

A review of studies conducted between 2001 and 2012 demonstrated that professional and lay healthcare workers had little or poor knowledge of HIV infection (Erasmus, Luiters \& Brijlal 2005:215; Hentgen et al. 2002:106; Prithiviraj 2012:66). The majority of the studies also focused on infection control policies and the knowledge, attitude and practices amongst all healthcare workers regarding oral lesions in HIV (Gachigo \& Naidoo 2001:589; King \& Muzzin 2005). These studies, except the recent study by Prithiviraj (2012), did not examine the levels of knowledge of healthcare workers regarding the oral manifestations of HIV infection and the management of these lesions. From reviewed research databases, there was only one study carried out on non-dental healthcare workers about the knowledge, attitudes and practices regarding oral manifestations of HIV in Lesotho (Prithiviraj 2012), but none had been carried out in South Africa.

\section{Definition of key concepts}

'Oral lesions in HIV-positive patients' refers to oral conditions experienced by HIV patients because of the compromised immune response that results from their HIV status. These lesions are classified according to the European Clearinghouse Classification (ECC) and the World Health Organization (WHO) (EC-Clearinghouse \& WHO 1993:290)

'A caregiver', for the purposes of this study, is a person from a community (ancillary or auxiliary) who worked at the chosen palliative care institutions and provided comprehensive healthcare and support for people infected and affected by $\mathrm{HIV}$ in the NGOs and CBOs. Such caregivers also included nurses.

\section{Research method and design}

Since 2001, the City of Johannesburg (CoJ) has been planning the development and implementation of programmes related to the prevention, care and support for people infected and affected by HIV (City of Johannesburg HIV/AIDS Programme (2004). At the time of this study in 2005-2006, 18 NGOs and CBOs situated in Region 8 provided various care and support programmes for people living with HIV (Dlamini \& Rudolph 2004). Only four of these organisations offered hospice or palliative care and they were thus selected to participate in this study. All 62 caregivers that worked in the hospice and palliative care centres in Region 8 of CoJ were recruited by the researchers to participate in the study. Fifty-two agreed to participate and gave informed consent.

\section{Data collection and measurement tool}

Data was anonymously collected on a paper-based questionnaire developed especially for the study. The questionnaire was designed to collect socio-demographic information from the caregivers as well as their KBP with regard to oral manifestations of HIV. Socio-demographic information collected included age, gender, marital status, level of education and employment status. The participants were categorised as ever married (separated, divorced, widowed or currently married) or never married. The participants were also categorised as being in full-time employment with the NGO or CBO or not (students, parttime caregivers or volunteers). The questionnaire also obtained information on the participants' practical experience as caregivers and, lastly, on their training in general homebased care and/or oral healthcare. 
The questions tested knowledge of common oral manifestations associated with HIV as classified by the ECC and the WHO (EC-Clearinghouse \& WHO 1993). Definitions of the oral lesions were described in common language in the questionnaire; for example, 'Can you identify oral thrush [Candidiasis]?' Caregivers were not trained on oral healthcare by the researcher prior to the study. The research aimed to ascertain the KBP of the caregivers with regard to oral care at that point in time.

The questionnaire comprised eight questions related to knowledge, six questions on beliefs and attitudes and extra questions on the socio-demographic characteristics of the respondents' data. Beliefs in this context were based on the theoretical construct that represented an individual's preference or dislike for an item or idea (Jong 1993). Beliefs are subjective and one can have a belief about an event or behaviour (Jong 1993). Questions on belief were based on the literature review on HIV, oral health and related risks from various literature reviewed (Erasmus et al. 2005; Hentgen et al. 2002; King \& Muzzin 2005; Marmy \& Matt 2003; Rudolph 1999; Thean, Wong \& Koh 2007).

It took each participant approximately 15 to 20 minutes to complete the questionnaire. The questionnaire was piloted at an NGO that was not involved in the main study. This was done in order to test for reliability, validity, comprehensibility, time taken to complete, feasibility and the degree to which the questions were interpreted and understood by different individuals.

During questionnaire testing, the respondents indicated that they did not understand the terminology in the questionnaire as stipulated in ECC classification regarding oral lesions in HIV (EC-Clearinghouse \& WHO 1993). Simple everyday language was then used to describe the lesions; for example, terms like candidiasis were amended to 'oral thrush' in the final questionnaire. After obtaining informed consent and appropriate ethical approval, the questionnaires were administered and completed while the investigator observed. Caregivers were allowed to ask for clarity on questions. Communication between caregivers was discouraged because it was important to obtain the KBP of each caregiver.

\section{Data analysis}

Stata 10 (StataCorp 2007) and SPSS version 19 (IBM Corp. 2010) statistical software were used for the analysis of data. Demographic information was described with means, standard deviations and frequencies. The reliability of the scales derived was assessed using Cronbach's $\alpha$-score. T-tests for independent samples were used to compare group differences, with interval data for statistical significance, whilst chi-square tests were used to compare group differences between categorical variables. To reduce the number of knowledge variables and to determine the patterns of knowledge, principal component analysis with varimax rotation was performed for questions concerning the knowledge of the caregivers. Factors were extracted using an Eigen value of $>1$ as the cut-off point. A $p$-value of $<0.05$ was considered to be statistically significant.

\section{Ethical considerations}

Approval for this study was obtained from the Human Research Ethics Committee (Medical) of the University of the Witwatersrand, Johannesburg, and clearance certificate number M050504 was provided. The approval from the university was conditional to the approval of the managers at the institutions. The managers of the institutions gave approval for the caregivers working at the institutions to be recruited and if the caregivers consented, they were to be included in the study. Participants who gave informed consent during recruitment were included in the study and completed the questionnaire.

\section{Results}

A response rate of $84 \%(52 / 62)$ was achieved. Of the caregivers, $65.4 \%$ had been trained in oral healthcare and the caregivers were subsequently divided into two categories those trained in oral healthcare (TOC) and those who had not received training in oral healthcare (NTOC).

The TOC caregivers were significantly older than the NTOC caregivers $(p=0.001)$. TOCs were also more likely to be females $(94.1 \%$ vs. $72 \% ; p=0.03)$, had been married $(58.8 \%$ vs. $27.8 \% ; p=0.03)$ and most were not employed on a full-time basis $(p=0.03)$ as compared with NTOCs. The majority of all the caregivers had an education level of Grade 12 and below and level of education was not associated with exposure to training in oral healthcare (Table 1 ). Nearly $66 \%$ of NTOC caregivers were trained in general home-based care $(11 \%$ of all caregivers) - a basic requirement for the staff of caregiving institutions, as opposed to $100 \%$ of TOCs $(p=0.001)$.

Following principal component analysis, two knowledge factors were revealed; these were called 'knowledge of specific lesions' and 'knowledge of oral care', explaining $40.4 \%$ and $34.3 \%$ of the common variance respectively (Table 2).

TABLE 1: Socio-demographic variables by groups.

\begin{tabular}{llll}
\hline Variable & $\begin{array}{l}\text { TOC }(N=34) \\
\%(N)\end{array}$ & $\begin{array}{l}\text { N TOC (N=18) } \\
\%(\mathbf{N})\end{array}$ & $p$-value* \\
\hline $\begin{array}{l}\text { Mean Age } \\
\text { Yrs (SD)† }\end{array}$ & $43.53(14.14) \dagger$ & $30.78(10.56) \dagger$ & 0.001 \\
$\begin{array}{l}\text { Gender \% (Freq.) } \\
\text { Female }\end{array}$ & $94.1(32)$ & $72.2(13)$ & \\
Male & $5.9(2)$ & $27.8(5)$ & \\
Total & $65.4(34)$ & $34.6(18)$ & 0.03 \\
Marital Status \% (Freq.) & & & \\
Ever Married & $58.8(20)$ & $27.8(5)$ & 0.032 \\
Never Married & $41.4(14)$ & $72.7(13)$ & \\
Employment Extent \% (Freq.) & & & \\
Full time & $67.6(23)$ & $94.4(17)$ & 0.028 \\
Not full time & $32.4(11)$ & $5.6(1)$ & \\
Education Level \% (Freq.) & & & 0.333 \\
Above Grade 12 & $32.4(11)$ & $22.2(4)$ & \\
Below Grade 12 & $67.6(23)$ & $77.8(14)$ & \\
\hline
\end{tabular}

Source: Author's own construction

$*$, Underlined $p$-value is significant at $5 \%$ level.

$\dagger$, SD, standard deviation; TOC, caregivers trained in oral care; NTOC, caregivers not trained in oral care; freq, frequency. 
TABLE 2: Summary of the results of factor analysis on caregivers' knowledge.

\begin{tabular}{|c|c|c|c|c|}
\hline Knowledge Scale domains & Factor variable & Factor loading & $\%$ variance (Rotated) & Cronbach's alpha \\
\hline \multirow[t]{5}{*}{ Factor 1: Specific lesions } & & - & $40.4 \%$ & 0.86 \\
\hline & Do you know the common mouth lesions found in HIV-positive patients? & 0.647 & - & - \\
\hline & Can you identify oral thrush? & 0.894 & - & - \\
\hline & $\begin{array}{l}\text { Can you identify hairy leukoplakia (white stripes on the tongue sides) in HIV-positive } \\
\text { patients? }\end{array}$ & 0.720 & - & - \\
\hline & $\begin{array}{l}\text { Can you identify linear gingival erythema (reddish line on the gum edges) in HIV- } \\
\text { positive patients? }\end{array}$ & 0.708 & - & - \\
\hline & Do you know any mouth-cleaning advice to give to HIV-positive patients? & 0.831 & - & - \\
\hline & Do you know proper tooth-brushing instructions to give to patients? & 0.761 & - & - \\
\hline & Do you know any mouth-rinsing regimen to advise on to HIV-positive patients? & 0.0780 & - & - \\
\hline & Do you know the referral procedure to give to HIV-positive patients? & 0.642 & - & - \\
\hline
\end{tabular}

All items

0.91

Source: Author's own construction

The TOC caregivers had higher mean scores on 'knowledge' variables in total and on the knowledge subdomains as compared with the NTOCs. The knowledge domain combined displayed an excellent internal consistency (Cronbach $\alpha$-score $>0.91)$. (See Table 3.)

An explorative factor analysis for caregivers' beliefs resulted in a single factor. The TOCs had higher belief frequency scores than the NTOCs. All the caregivers agreed that 'oral care is very important in HIV-positive patients' and that learning more about the mouth care of HIV-positive patients was important (Figure 1). The caregivers differed significantly in their responses and opinions regarding mouth care. In general, the majority of NTOCs reported negative beliefs $(p<0.05)$.

The majority of NTOC caregivers were concerned about the risk of infection from treating HIV-infected patients as compared with the TOC caregivers $(78 \%$ vs. $15 \%$; $p<0.05)$ (Figure 1), as shown in their responses to the statement 'Cleaning the mouth increases the risk of HIV infection for caregivers'.

The caregivers trained in general home-based care had higher scores on the knowledge of 'oral care' but there was no difference in scores regarding knowledge of 'specific lesions' in HIV infection (Table 4).

The higher the education level, the higher the scores on both knowledge subdomains when those caregivers with higher than Grade 12 were compared with those with or below Grade 12. There was no difference in the 'belief' scores between those with higher and lower education levels (Table 5).

The nature of employment, whether full time or not, did not affect the 'knowledge' scores, as there was no significant difference. The nature of employment, however, influenced both 'belief' and 'self-reported practice' scores. Those not working full time had higher scores compared with those working on a full-time basis $(p<0.05)$. The higher the score, the more positive the 'beliefs'. Those not working full-time also reported more involvement in tending to the mouth infections of the HIV patients $(p<0.05)$.
TABLE 3: Knowledge subdomains of the caregivers by training in oral health care.

\begin{tabular}{llllll}
\hline Knowledge & $\begin{array}{l}\text { Training in oral } \\
\text { health care }\end{array}$ & $\boldsymbol{N}$ & Mean & $\begin{array}{l}\text { Standard } \\
\text { deviation }\end{array}$ & p-value* \\
\hline Total & TOC & 34 & 6.24 & 2.36 & - \\
& NTOC & 17 & 3.71 & 3.18 & 0.008 \\
Specific lesion & TOC & 34 & 3.32 & 1.224 & - \\
& NTOC & 17 & 2.29 & 1.724 & 0.037 \\
Oral care & TOC & 34 & 2.92 & 1.53 & - \\
& NTOC & 17 & 1.42 & 1.66 & 0.002 \\
\hline
\end{tabular}

Source: Author's own construction

$*$, Underlined $p$-value is significant at $5 \%$ level.

TOC, caregivers trained in oral care; NTOC, caregivers not trained in oral care.

TABLE 4: Knowledge of caregivers by training in general home-based care.

\begin{tabular}{llllll}
\hline Variable & $\begin{array}{l}\text { Training in general } \\
\text { home-based care }\end{array}$ & $\boldsymbol{N}$ & Mean & $\begin{array}{l}\text { Standard } \\
\text { deviation }\end{array}$ & p-value* \\
\hline Knowledge $_{\text {Total }}$ & Yes & 46 & 6.45 & 3.146 & - \\
& No & 5 & 4.00 & 1.871 & 0.038 \\
Knowledge $_{\text {Specific lesion }}$ & Yes & 46 & 3.06 & 1.467 & - \\
& No & 5 & 2.20 & 1.483 & 0.217 \\
Knowledge $_{\text {Oral care }}$ & Yes & 46 & 3.39 & 1.971 & - \\
& No & 5 & 1.80 & 0.837 & 0.007 \\
\hline
\end{tabular}

Source: Author's own construction

$*$, Underlined $p$-value is significant at $5 \%$ level.

There was a difference in the 'knowledge' scores categorised by marital status $(p<0.05)$. Those who were 'ever married' (i.e. they were once married or still married) had higher knowledge scores. However, there was no difference in the belief and practice scores in this group.

The 'practices' variable measured the self-reported extent of involvement regarding specific symptoms. The self-reported extent of involvement by NTOC caregivers was higher than that reported by the TOCs $(p<0.05)$. In particular, the involvement in addressing symptoms not specific to HIVassociated oral lesions (e.g. toothache and gingivitis) was significantly higher amongst the NTOCs $(p=0.05)$.

All the caregivers were required to respond to questions regarding action regarding and management of specific common oral symptoms. The NTOC caregivers reported providing 'inappropriate management' for some oral symptoms as illustrated (Evian 2003). For example, the NTOCs were less likely to refer patients with bleeding gums to professionals. They were also less likely to provide advice on oral hygiene and were the only ones who reported 


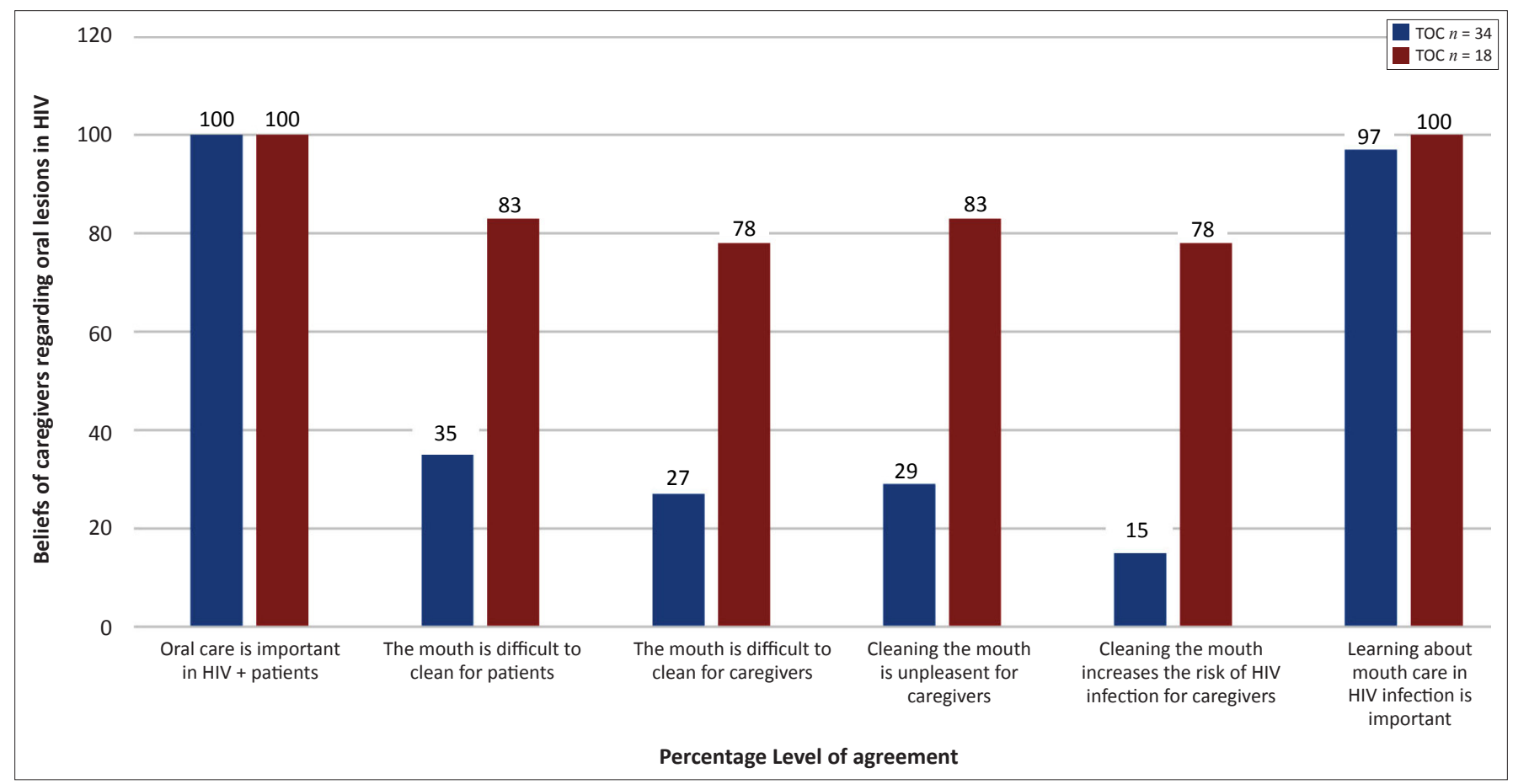

Source: Author's own construction

FIGURE 1: Beliefs of caregivers regarding oral health care in HIV-positive patients.

TABLE 5: Knowledge and beliefs of caregivers compared to their education level

\begin{tabular}{|c|c|c|c|c|c|}
\hline Variable & Education Level & $N$ & Mean & Standard deviation & $p$-value* \\
\hline \multirow[t]{2}{*}{ Knowledge $_{\text {Total }}$} & Above Grade 12 & 14 & 8.00 & 2.480 & - \\
\hline & Grade 12 and below & 37 & 5.54 & 3.097 & 0.006 \\
\hline \multirow[t]{2}{*}{ Knowledge ${ }_{\text {Specific lesion }}$} & Above Grade 12 & 14 & 3.71 & 1.069 & - \\
\hline & Grade 12 and below & 37 & 2.70 & 1.525 & 0.012 \\
\hline \multirow[t]{2}{*}{ Knowledge $_{\text {Oral care }}$} & Above Grade 12 & 14 & 4.29 & 1.541 & - \\
\hline & Grade 12 and below & 37 & 2.84 & 1.951 & 0.009 \\
\hline \multirow[t]{2}{*}{ Beliefs ${ }_{\text {Cleaning mouth }}$} & Above Grade 12 & 15 & 7.81 & 3.487 & - \\
\hline & Grade 12 and below & 37 & 7.81 & 3.487 & 0.126 \\
\hline
\end{tabular}

Source: Author's own construction

$*$, Underlined $p$-value is significant at $5 \%$ level.

that they would recommend acyclovir cream following complaints of bleeding gums (Table 6).

\section{Validity and Reliability}

The study findings reflect the actual reported experiences of the caregivers. Statistical quantitative analysis and rigour was applied in order to bring out the significance of the result.

\section{Reliability}

The results of the study can be declared reliable because the research tool had good internal consistency after applying the Cronbach $\alpha$-test.

\section{Validity}

The study truthfully and correctly reflects the self-reported levels of KBP of the caregivers. The research was aimed at ascertaining the $\mathrm{KBP}$ of the caregivers at that point in time of the study. A thorough data collection process and rigorous analysis produced the current findings to generate a hypothesis around the theme topic, notwithstanding the mentioned limitations.
TABLE 6A: Self-reported practices provided for the symptoms bleeding gums and sores in the mouth.

\begin{tabular}{|c|c|c|c|}
\hline $\begin{array}{l}\text { Self-reported practices of caregivers } \\
\text { for bleeding gums }\end{array}$ & $\begin{array}{l}\text { TOCs } \\
(N=21)\end{array}$ & $\begin{array}{l}\text { NTOCs } \\
(N=14)\end{array}$ & $p$-value * \\
\hline Gargle with salty water, eat fruits & $33.3(7)$ & $14.3(2)$ & 0.19 \\
\hline $\begin{array}{l}\text { Refer to clinic/doctor/report to sister } \\
\text { in charge }\end{array}$ & $38.1(8)$ & 0 & 0.009 \\
\hline Acyclovir cream/tablets & 0 & $35.7(5)$ & 0.006 \\
\hline Soft diet, brush softly/no fizzy drinks & 0 & $50(7)$ & 0.000 \\
\hline Other & $28.7(6)$ & 0 & 0.033 \\
\hline
\end{tabular}

Source: Author's own construction

$*$, Underlined $p$-value is significant at $5 \%$ level.

TOC, caregivers trained in oral care; NTOC, caregivers not trained in oral care.

TABLE 6B: Self-reported practices provided for the symptoms bleeding gums and sores in the mouth.

\begin{tabular}{llll}
\hline $\begin{array}{l}\text { Self-reported practices of caregivers } \\
\text { for sores in the mouth }\end{array}$ & $\begin{array}{l}\text { TOCs } \\
(N=23)\end{array}$ & $\begin{array}{l}\text { NTOCs } \\
(N=14)\end{array}$ & $p$-value * \\
\hline Oral hygiene/gargle with mouthwash & $39(9)$ & $28.6(4)$ & 0.8 \\
Refer to doctor/sister & $30(7)$ & $14.3(2)$ & 0.42 \\
$\begin{array}{l}\text { No spicy food } \\
\begin{array}{l}\text { Advise to drink pure juice and soft } \\
\text { porridge }\end{array}\end{array}$ & $0.01(2)$ & $57(8)$ & 0.00 \\
Other & $34.7(8)$ & $14.3(2)$ & - \\
\hline
\end{tabular}

Source: Author's own construction

*, Underlined $p$-value is significant at $5 \%$ level.

TOC, caregivers trained in oral care; NTOC, caregivers not trained in oral care. 


\section{Discussion}

The current study determined the knowledge, beliefs and self-reported practices of non-dental healthcare workers in relation to the oral manifestations of HIV using a new questionnaire. The study showed that most of the caregivers had been trained in oral healthcare and that the training was associated with their KBP relating to care for HIV oral lesions.

It was not surprising from the results that most caregivers were female: this fact was in alignment with the gender of most primary caregivers (Neal, Ingersoll-Dayton \& Starrels 1997:815).

The national guidelines require that all caregivers should be trained before engagement in comprehensive care and support for people living with HIV. Of concern was that $33 \%$ of NTOC caregivers, which is $11 \%$ of all caregivers in this study, had not received training in general home-based care.

Factor analysis for the caregivers' knowledge revealed factors in line with general oral healthcare such as tooth-brushing instructions and mouth rinsing. Knowledge of specific lesions seemed to be according to the ECC classification of common oral lesions in HIV infection (EC-Clearinghouse \& WHO 1993:290). NTOC caregivers were more likely not to have knowledge of specific lesions associated with HIV infection and knowledge pertaining to oral care for common oral lesions as compared with the TOC caregivers $(p<0.005)$. The better knowledge reported in the current study is in agreement with the 2004 study by Mynors-Wallis \& Davis (2004:202), where a dental talk to a group of old-age home nursing staff produced a significant increase in the level of oral healthcare knowledge and hence in the oral healthcare of patients (Mynors-Wallis \& Davis 2004:202). Results from this study are also similar to findings in a study by Frenkel, Harvey and Needs (2002), where an oral healthcare education programme resulted in improved oral healthcare knowledge and attitudes amongst the nursing home caregivers (Frenkel et al. 2002:99). In Frenkel et al.'s study, as well as in the current study, knowledge was affected in a positive manner when caregivers had a higher education level but was not affected by the caregivers' working experience.

The caregivers' beliefs were affected by the nature of their employment, whether full time or not. The caregivers who were not in full-time employment had more positive beliefs than those who worked full time. This could be explained by the fact they did not have to be in constant contact with sick patients and dreaded going to work less than those caregivers who were employed full time in caring for the mouth infections of the HIV-positive patients. Caregiving often results in chronic stress, which has a negative impact on caregivers' psychological health. Depression and negative mental states are common effects of caregiving (Schullz \& Sherwood 2008:23). This may suggest the need for regular debriefing for those in full-time employment in order to alleviate the potential of psychological fatigue resulting from regular contact with those suffering from debilitating diseases.
Negative attitudes and beliefs are usually associated with little or no knowledge about a particular topic. Necessary support (training) and knowledge are important with regard to changing beliefs and supporting the positive attitudes of the trained caregivers (Jong 1993). For instance, in a randomised controlled trial on nursing home caregivers, a training intervention significantly improved the knowledge and belief scores in the intervention group (Frenkel et al. 2002:99). Thean et al. (2007) reported, in a pilot study to assess the oral health knowledge amongst staff in a nursing home, that nearly all (99.6\%) of the respondents felt that the oral healthcare of the elderly was very important. In the current study, the caregivers who reported being trained in oral care in addition to being trained in general home-based care had more positive beliefs regarding caring for the mouths of HIV-infected patients. Being 'trained in oral healthcare' and 'general home-based care' appears to have created positive attitudes toward caring for the mouth infections of the HIVpositive patients and might conceivably have influenced their beliefs

In the current study, the belief surrounding 'cleaning the mouth' included concern about the risk of infection. The NTOC caregivers had negative beliefs about infection risk and this was of concern because their beliefs might result in compromised care for their HIV-positive patients.

The findings are similar to findings of negative perceptions and beliefs as shown in numerous KBP surveys where the majority of health workers feared becoming infected when attending to HIV-positive patients (Erasmus et al. 2005:216; King \& Muzzin 2005).

Taking into consideration the inherent limitation of selfreporting and the fact that it could lead to the Hawthorne effect, the self-reported practices or nature and extent of involvement in addressing presenting symptoms was unexpected. The TOC caregivers reported less involvement with the reported patients' complaints than the NTOCs. In addition, those who had been trained in general home-based care reported more involvement than those who were not trained in general home-based care. The level of education did not alter the self-reported nature of involvement or practices of the caregivers.

This reporting is of concern if the untrained caregivers report actually taking action or giving advice to the patients, because it could imply that the information and/or action is inappropriate or not within standard procedures. Caregivers are meant to support the patients and assist with symptom management. It is preferable for the caregivers to refer management of unfamiliar complaints for professional management. Indeed, it would appear that this was the case, as further analysis of reported advice given to patients by NTOCs appeared inappropriate (Evian 2003). For instance, NTOC caregivers reported being less likely to refer patients with bleeding gums - which could be a symptom of serious ailment - to professionals. The NTOCs also reported being less likely to provide advice on oral hygiene and were the 
only ones who reported they would recommend acyclovir cream and no fizzy drinks following complaints of bleeding gums.

\section{Limitations of the study}

A new questionnaire was developed and used for data collection. Although this questionnaire was used for the first time, it was piloted for reliability and validity and found to have good internal consistency and can therefore be used to assess the caregivers' knowledge. Factor analysis revealed items that correlated with the current body of knowledge regarding 'routine oral healthcare' and 'specific lesions'.

This was a cross-sectional study based on self-reporting and was, therefore, subject to reporting bias. Furthermore, only limited inferences can be made on causality. Cross-sectional studies are performed at one point in time, which makes two different and distinct variables that have to be measured at the same time. This factor doesn't allow for establishing the sequence of events, including those which might have occurred concurrently. Therefore, only associations between variables can be concluded but not whether one variable causes the other.

The sample was limited to the whole population of 52 respondents; however, the study was only a pilot survey. This small number made it impossible to adjust for potential confounders. Although this was a small study, it generated a hypothesis on the possible knowledge trends and in this way becomes a basis for further research. The study thus remains a useful baseline for larger well-controlled follow-up studies.

\section{Clinical significance}

Despite these limitations, the findings of this study provide useful information that can inform interventions to improve HIV patients' access to quality, cost-effective oral healthcare. Caregivers' institutions can be evaluated and caregivers' knowledge can be assessed using tools such as the questionnaire used in this study to get feedback regarding the practice of the caregivers. The questionnaire will provide a quick snapshot of the current practice. Following evaluation, proper corrective measures such as capacity building can be instituted, should the need arise.

\section{Recommendations}

Bearing in mind the limitations of 'knowledge, beliefs and practices' surveys and the cross-sectional design of the study, the following recommendations are made:

- The measurement tool has been validated for this population. It is therefore recommended that a larger sample with different demographics be used to validate the tool. A larger study should be extended to other regions or provinces so that associations and correlations between various variables can be probed. It is further recommended that a larger study look at the gaps between participants' actual and perceived knowledge.
- Training in basic home-based care should be a prerequisite before any caregivers are allowed to interact with patients in order to provide proper supportive care.

- Training in oral healthcare and refresher courses for those trained must be incorporated into the programme of all caregivers working in palliative institutions. Such training would provide specialised knowledge about oral health and oral lesions in HIV infection and thus improve caregivers' current knowledge, attitudes and practices, including making appropriate referrals or professional management of HIV-specific lesions.

- Training workshops should be initiated in all the NGOs and CBOs providing palliative care and support, as well as in other institutions, in order not to further disadvantage the users of these facilities.

\section{Conclusion}

The study findings suggest that the caregivers' knowledge levels with regard to caring for oral lesions in HIV infection were better amongst those caregivers who reported receiving prior training, specifically in oral healthcare (TOC). The caregivers' knowledge was also associated with training in general home-based care, marital status and their education level. The caregivers who reported being also trained in general home-based care in addition to being TOC had higher knowledge levels on 'oral care'. The higher the education level of caregivers, the higher the knowledge levels on both 'specific lesion in HIV' and on routine 'oral care'.

The findings also demonstrate that the caregiver's beliefs about oral care for HIV lesions were better in caregivers who reported prior TOC. The TOC caregivers were more positive toward caring for patients with oral lesions in HIV and the risk related to HIV infection. However, all caregivers acknowledged that oral care is important for HIV patients and that learning more about mouth care in HIV infection is essential. Beliefs were also influenced by work type (i.e. whether working full time or not). Those working part time seemed to feel more positive as compared to those employed full time.

With regards practices (nature and/or extent of involvement) of caregivers regarding care for oral lesions in HIV patients, those who reported to have received previous TOC reported having provided appropriate care as stipulated by the guidelines. In addition, the TOCs seemed more likely to be cautious in providing care for the patients and rather referred patients for professional management of oral lesions when not sure. This study's findings highlight the importance of training caregivers as part of efforts to improve the standard of care to those living with HIV.

\section{Acknowledgements}

I would like to acknowledge Prof. M.J. Rudolph and Dr V. Yengopal for their involvement and advice with the project. I remain very grateful to the caregivers interviewed in the study for their contributions. 


\section{Competing interests}

The authors declare that they have no financial or personal relationship(s) which may have inappropriately influenced them in writing this article.

\section{Authors' contributions}

Y.K. (University of Pretoria) was the project leader and responsible for most of the project design, data collection and wrote the manuscript. O.A.A-Y. (University of Pretoria) performed all the statistical analysis and made conceptual contributions regarding the content of the manuscript.

\section{References}

City of Johannesburg HIV/AIDS Programme, 2004, 'Document prepared for the Corporate Planning Unit in the Office of the City Manager of the City of Johannesburg', viewed February 2013, from www.joburg.org.za/corporate planning/aids.pdf

Coogan, M.M., Greenspan, J. \& Challacombe, S.J., 2005, 'Oral lesions in infection with human immunodeficiency virus', Bulletin of the World Health Organization 83(9), 700-706.

Department of Health, 2001, National guidelines on home based care \& community based care, Department of Health, Pretoria.

Dlamini, S. \& Rudolph, M.J., 2004, 'Impact of NGOs/CBOs Providing Care and Support for People Infected \& Affected by HIV/AIDS in Region 8, City of Johannesburg', unpublished publication, Faculty of Health Sciences, Department of Community Dentistry, University of the Witwatersrand.

EC-Clearinghouse \& WHO Collaborating Centre on Oral Manifestations of the Immunodeficiency Virus, 1993, 'Classification and diagnostic criteria for oral lesions in HIV infection', Journal of Oral Pathology and Medicine 22(7), 289-291. http://dx.doi.org/10.1111/j.1600-0714.1993.tb01074.x, PMid:8229864

Erasmus, S., Luiters, S. \& Brijlal, P., 2005, 'Oral hygiene and dental students' knowledge, attitude and behaviour in managing HIV/AIDS patients', International Journal of Dental Hygiene 3(4), 213-217. http://dx.doi.org/10.1111/j.160150urnal of Dental Hygiene 3(4),
5037.2005.00137.x, PMid:16451310

Evian, C., 2003, Primary AIDS Care, 4th edn., Jacana Media, Fishwicks the Printers, Durban.

Frenkel, H., Harvey, I. \& Needs, K., 2002, 'Oral health care education and its effect on caregivers' knowledge and attitudes: a randomised controlled trial', Community Dental Oral Epidemiology 30(2), 91-100. http://dx.doi.org/10.1034/j.16000528.2002.300202.x
Gachigo, J. \& Naidoo, S., 2001, 'HIV/AIDS: the knowledge, attitudes and behaviour of dentists in Nairobi, Kenya', South African Dental Journal 56(12), 587-591.

Hentgen, V., Jaureguiberry, S., Ramiliarisoa, A., Andrianantoandro, V. \& Belec, M., 2002, 'Knowledge, attitude and practices of health personnel with regard to HIV/AIDS in Tamatave (Madagascar)', Bulletin for Social Pathology Exotica 95(2), 103-108.

Human Sciences Research Council, 2008, 'South African national HIV prevalence, HIV incidence, behaviour and communication Survey', viewed February 2013, from http://www.mrc.ac.za/pressreleases/2009/sanat.pdf

IBM Corp., Released 2010, IBM SPSS Statistics for Windows, Version 19.0., IBM Corp., Armonk, N.Y.

Jong, A., 1993, Community dental health, Mosby, St Louis, MO

King, T.B. \& Muzzin, K.B., 2005, 'A national survey of dental hygienists' infection control attitudes and practices', Journal of Dental Hygiene 79(2), 8.

Lim, A.A., Leo, Y.S., Lee, C.C. \& Robinson, A.N., 2002, 'Oral manifestations of human immunodeficiency virus (HIV)-infected patients in Singapore', Annals of Academic Medicine in Singapore 30(6), 600-606.

Malele, Y., 2007, 'An assessment of the effectiveness of Andolex-C ${ }^{\circledR}$ mouth rinse on oral palliation in HIV-infected patients', Master's thesis, Faculty of Health Sciences, Department of Community Dentistry, University of Witwatersrand Johannesburg, viewed 30 January 2009, from http://wiredspace.wits.ac.za/ handle/10539/5829

Marmy, M. \& Matt, F., 2003, 'Oral hygiene knowledge of caregivers in a psychogeriatric home', Schweiz Monatsschr Zahnmed 113(7), 787-800.

Mynors-Wallis, J. \& Davis, D.M., 2004, 'An assessment of the oral health knowledge and recall after a dental talk amongst nurses working with elderly patients: a
pilot study', Gerodontology 21(4), 201-204. http://dx.doi.org/10.1111/j.1741pilot study', Gerodontology 21(4), 201
2358.2004.00036.x, PMid:15603278

Neal, M.B., Ingersoll-Dayton, B. \& Starrels, M.E., 1997, 'Gender and relationship differences in caregiving patterns and consequences among employed caregivers', The Gerontologist 37(6), 804-816. http://dx.doi.org/10.1093/geront/37.6.804, PMid:9432997

Prithiviraj, T.G., 2012, 'The knowledge, attitude and practice among primary health care nurse practitioners regarding oral health and oral HIV lesions in QE II and Roma health service areas in Maseru, Lesotho', Master's thesis, Faculty of Health Sciences, University of Witwatersrand, Johannesburg, viewed February 2013 from http://wiredspace.wits.ac.za/handle/10539/11441

Rudolph, M.J. \& Ogunbodede, E.O., 1999, 'HIV infection and oral health care in South Africa', South African Dental Journal 54(12), 594-601.

Schullz, R. \& Sherwood, P.R., 2008, 'Physical and mental health effects of family caregiving', American Journal of Nursing 108(9) (Suppl), 23-27. http://dx.do org/10.1097/01.NAJ.0000336406.45248.4c, PMid:18797217 PMCid:2791523

StataCorp., 2007, Stata Statistical Software, Release 10, StataCorp LP, College Station, TX.

Thean, H., Wong, M.L., Koh, H., 2007, 'The dental awareness of nursing home staff in Singapore - a pilot study', Gerodontology 24(1), 58-63. http://dx.doi. org/10.1111/j.1741-2358.2007.00138.x, PMid:17302933

Yengopal, V. \& Naidoo, S., 2008, 'Do oral lesions associated with HIV affect quality of life?', Oral Surgery Oral Medicine Oral Patholology Oral Radiolology Endodontics 106(1), 66-73. http://dx.doi.org/10.1016/j.tripleo.2007.12.024, 